\title{
PENINGKATAN PENGETAHUAN DAN PERILAKU PENCEGAHAN HIV DARI IBU KE BAYI DENGAN MEDIA BOOKLET
}

\author{
Mira Meliyanti \\ Program Studi Diploma Tiga Kebidanan STIKes Dharma Husada Bandung \\ mirazallea@gmail.com
}

\begin{abstract}
Abstrak
Cakupan pelaksanaan skrining triple eliminasi di Kabupaten Bandung Barat masih rendah. Salah satu faktor yang berpengaruh dalam pelaksanaan peningkatan pengetahuan dan perilaku adalah Pendidikan kesehatan. Berbagai cara dapat dilakukan untuk meningkatkan dukungan salah satunya dengan memberikan Pendidikan tentang pencegahan HIV/AIDS pada ibu ke bayi melalui booklet.

Tujuan penelitian untuk M mngetahui pengaruh pemberian booklet terhadap peningkatan pengetahuan dan perilaku pada ibu hamil tentang pencegahan HIV/AIDS pada ibu ke bayi.

Penelitian ini adalah penelitian eksperimen dengan menggunakan rancangan pre test and posttest with control group yang dilaksanakan pada bulan November s.d Februari 2021. Sampel studi penelitian ini adalah seluruh ibu usia reprodukstif yang datang ke wilayah kerja PMB kabupaten bandung barat. Sesuai dengan kriteria inklusi dan eksklusi. Dengan sampel 96 orang. Analisis data menggunakan independent $t$-test, dan MANOVA. Alat ukur yang digunakan adalah kuesioner.

Terdapat perbedaan peningkatan pengetahuan antara dua kelompok dengan $p$-value $=0.026$, terdapat perbedaan peningkatan sikap antara dua kelompok dengan $p$-value $=0.015$. bahwa terdapat perbedaan peningkatan dukungan antara dua kelompok dengan $p$-value $=0.018$.

Ada pengaruh pemberian booklet terhadap peningkatan pengetahuan dan prilaku pada ibu hamil.
\end{abstract}

Kata Kunci: Booklet, Pengetahuan, Wanita

\section{PENDAhuluan}

Penyakit HIV/AIDS merupakan suatu penyakit yang terus berkembang dan menjadi masalah global yang melanda dunia. Masalah HIV/AIDS diyakini bagaikan fenomena gunung es karena jumlah kasus yang dilaporkan tidak mencerminkan masalah yang sebenarnya (Hardisman, 2009).

Pada tahun 2015, Indonesia menduduki peringkat kedua yang diestimasikan sebagai penyumbang orang dengan HIV/AIDS terbanyak di Asia Tenggara setelah India (60\%) yakni sebesar $20 \%$ atau 690.000 ODHA (WHO, 2016). Tahun 2016, Indonesia mengalami kenaikan kejadian insiden HIV menjadi 41.250 orang yang sebelumnya sebesar 30.935 orang pada tahun 2015. Hasil estimasi dan proyeksi jumlah orang dengan HIV/AIDS pada umur > 15 tahun di Indonesia pada tahun 2016 sebanyak 785.821 orang dengan jumlah infeksi baru sebanyak 90.915 orang dan kematian sebanyak 40.349 orang (Ditjen P2P Kemenkes RI, 2016).

Menurut jenis kelamin, penderita HIV/AIDS pada laki-laki masih lebih besar dibandingkan perempuan. HIV positif pada laki-laki $(63,3 \%)$, perempuan $(36,7 \%)$. Penderita AIDS laki-laki (67,9\%), perempuan 
(31,5\%). Proporsi HIV/AIDS terbesar masih pada penduduk usia produktif (15-49 tahun) yang dibagi dalam tiga golongan umur yaitu 15-19 tahun (3,7\%), 20-24 tahun (17,3\%), dan 25-49 tahun (69,3\%), dimana kemungkinan penularan terjadi pada usia remaja (Kemenkes RI, 2017).

Peningkatan kasus HIV pada ibu rumah tangga dapat berdampak peningkatan status epidemic dari terkonsentrasi menjadi generalized apidemic. Jika ibu rumah tangga terinfeksi HIV berisiko meningkatkan epidemi menjadi generalized epidemic dimana hal tersebut dapat mengakibatkan penularan HIV pada ibu hamil serta meningkatkan penularan HIV melalui perinatal (ke anak).

Pesatnya pengaruh penggunaan media sosial menimbulkan dampak pada cara pergaulan zaman sekarang yang sudah mulai bebas, serta masih kurangnya pemberian pendidikan kesehatan terkait HIV. Oleh karena itu sesuai Permenkes No.21 tahun 2013 tentang penanggulangan HIV/AIDS, bahwa salah satu upaya penanggulangan HIV dengan melakukan pendidikan kesehatan, bisa melalui iklan masyarakat maupun promosi kesehatan.

Dalam penyampaian pendidikan kesehatan terhadap masyarakat, terdiri dari tiga metode yaitu metode pendidikan individual, metode pendidikan kelompok dan metode pendidikan masa. Pendidikan kesehatan dapat lebih dipahami oleh peserta dengan bantuan media. Media atau alat bantu pendidikan kesehatan merupakan alat yang digunakan oleh petugas kesehatan dalam menyampaikan bahan materi atau pesan kesehatan. Macam-macam media pendidikan kesehatan diantaranya visual aids seperti film pendek, audio aids seperti radio, audio visual aids seperti, televisi dan media cetak seperti booklet, leaflet, flip chart, komik, dan lainlain (Notoatmodjo, 2014). Pendidikan kesehatan yang dilakukan dalam penelitian ini yaitu menggunakan media booklet. Booklet merupakan buku yang terdapat gambar dan dilengkapi dengan kata-kata yang menjelaskan gambar (Nurgiyantoro, 2005).

Menurut Rohani dan Yuniarti (2014), Booklet merupakan media grafis yang mengkomunikasikan fakta-fakta dan gagasan secara jelas dan kuat melalui perpaduan antara kata-kata dan gambar. Booklet mempunyai komponen-komponen yang kaya akan warna serta gambar dan dilengkapi dengan tulisan untuk menjelaskan gambar, sehingga orang akan lebih tertarik untuk membaca dan dapat melatih untuk berpikir kreatif serta mengembangkan proses berpikir kognitif. Selain itu, media booklet sebagai media visual lebih ekonomis dan lebih terjangkau jika dibandingkan dengan media audio-visual yang membutuhkan teknologi canggih dalam penggunaannya (Backes, 2007).

Hasil penelitian sebelumnya yang dilakukan oleh Wibowo (2014), 
menyimpulkan bahwa terjadi peningkatan pengetahuan Dirgantara Karanganyar setelah diberi pendidikan kesehatan dengan metode pemutaran film dan media leaflet. Hasil penelitian Khoiri (2015), menyimpulkan bahwa terjadi peningkatan rata-rata skor pengetahuan dan sikap setelah diberikan penyuluhan dengan media video dan leaflet. Berdasarkan hasil penelitian Handayani (2010), menyimpulkan pengaruh media buku komik lebih besar dari media leaflet terhadap peningkatan pengetahuan dan sikap terhadap gaya sehat ibu hamil sebelum dan sesudah diberikan perlakuan.

Sejalan penelitian diatas, hasil penelitian Shobirin (2013), menyimpulkan ada pengaruh penyuluhan kesehatan media buku komik terhadap peningkatan pengetahuan dan sikap dalam pemberantasan sarang nyamuk Demam Berdarah Dengue (PSN-DBD), serta hasil penelitian Rohim, dkk (2016) juga menyimpulkan bahwa terjadi kenaikan tingkat pengetahuan setelah diberikan pendidikan kesehatan dengan media buku cerita dan ceramah tentang anemia pada remaja putri. Dari hasil penelitian Fadilah (2010), menyimpulkan bahwa booklet berpengaruh terhadap pengetahuan remaja tetapi tidak berpengaruh terhadap sikap remaja terkait kesehatan reproduksi, lalu hasil penelitian Ma'munah (2015), menyatakan bahwa booklet berpengaruh positif meningkatkan pengetahuan tentang nutrisi ibu menyusui.
Dalam penelitian ini, peneliti menggunakan media booklet, karena jika menggunakan media pemutaran film dan video memerlukan biaya yang mahal dan memerlukan tenaga ahli dalam membuat media audio visual, sedangkan penggunaan leaflet mempunyai kelemahan karena ukurannya yang kecil, mengakibatkan mudah hilang, dan mudah rusak serta karena isinya yang singkat, diperlukan pengetahuan yang lebih dalam memahami isi leaflet yang disampaikan. Sedangkan jika menggunakan media komik dan buku cerita bergambar, akan mempunyai kelemahan seperti orang menjadi malas karena akan cenderung ingin melihat gambar yang menarik menurut mereka saja, dan tidak memahami materi secara utuh. Bahkan enggan untuk membaca keseluruhan cerita sehingga daya serap siswa terhadap materi rendah (Kusrianto, 2009).

Penggunaan metode ceramah tanpa media sudah sering digunakan dalam memberikan pendidikan kesehatan terkait HIV/AIDS baik dalam kelompok kecil maupun kelompok besar, namun belum ada penurunan angka kejadian HIV/AIDS, bahkan cenderung meningkat setiap tahunnya, selain itu ceramah juga memiliki kelemahan seperti membuat ibu hamil dan jika terlalu lama, siswa akan merasa bosan. Karena hal ini, peneliti tertarik memberikan pendidikan kesehatan kepada ibu hamil terkait HIV/AIDS melalui media booklet, karena untuk memperbaharui media yang 
digunakan dalam pendidikan kesehatan terkait HIV/AIDS, dan masih jarangnya penggunaan media booklet pada ibu hamil dalam memberikan informasi terkait HIV.

Pengembangan media pendidikan kesehatan tidak hanya mencakup pesan tertulis melainkan juga gambar untuk memudahkan pemahamanan tentang pesan. Berdasarkan hal tersebut, peneliti tertarik untuk menguji media yang memuat pesan tertulis dan gambar berupa booklet. Media booklet sangat membantu sasaran pendidikan karena dapat menyimpan pesan dalam dua bentuk, yaitu pesan bentuk tulis (verbal tulis) dan gambar (non verbal). Gambar itu sendiri dapat membantu sasaran dalam mempersepsikan objek pesan yang diterima. Bahasa tulis juga disusun dengan mempertimbangkan bahasa yang mudah diterima oleh semua orang agar betul-betul relevan dengan subjek. Hal ini terbukti dengan penelitian yang dilakukan oleh Ridha dan Andri (2016), bahwasannya media booklet cocok diberikan kepada sasaran ibu hamil.

Studi pendahuluan yang dilakukan di Praktek Mandiri Bidan (PMB) Bidan Y, dilakukan kepada 16 ibu hamil. Dari 16 ibu hamil, didapatkan hasil bahwa 14 ibu hamil berpengetahuan cukup, sedangkan 2 ibu hamil lainnya memiliki pengetahuan kurang. 10 ibu hamil memiliki sikap positif dan 6 orang bersikap negatif dan semua ibu hamil sudah pernah mendengar informasi tentang
HIV. Jika dilihat dari waktu tertular HIV hingga terdiagnosa sebagai AIDS yakni sekitar 5-10 tahun, dapat diperkirakan bahwa virus HIV sudah ada di dalam tubuh pada saat usia remaja, oleh karena itu peneliti tertarik untuk melakukan penelitian mengenai pengaruh pendidikan kesehatan dengan media booklet terhadap Peningkatan pengetahuan penularan HIV dari ibu ke bayi.

\section{METODOLOGI PENELITIAN}

Penelitian dilaksanakan di PMB wilayah kerja Dinas kesehatan Kabupaten bandung Barat yaitu di bidan F, bidan R, bidan Y, pada bulan April sampai dengan Mei 2021. Metode penelitain adalah eksperimnen dengan menggunakan ramcangan pretest dan posttesd with control group dengan pendekatan cross sectional. Sampel penelitian adalah ibu usia reproduktif wilayah kerja Dinas Kesehatan Kabupaten Bandung Barat yg datang ke PMB bidan F, bidan R, bidan Y, sebanyak 96 orang.

Instrumen penelitian yang digunakan berupa kuesioner untuk ibu hamil, yaitu HOME (Home Observation for Measurement of the Environment. Pengkategorian dalam pendidikan kesehatan terhadap tingkat pengetahuan HIV/AIDS dengan menggunakan media booklet ini menggunakan rata - rata pencapaian skor. Pengkatagorian rata - rata pencapaian skor ini menggunakan 3 variasi yaitu katagori rendah, bila nilai total 0-29, sedang, bila nilai total $30-45$ dan baik, bila nilai total 46-55. 
Analisa data yang digunakan adalah analisa univariat dan bivariat. Analisa univariat menghasilkan distribusi frekuensi dan persentasi dari setiap variabel. Analisa bivariat menggunakan uji chi square untuk mengetahui hubungan antara variabel bebas dan variabel terikat.

\section{HASIL DAN PEMBAHASAN}

\section{A. Hasil}

\section{Tabel 1 Distribusi Frekuensi Tingkat Pengetahuan Ibu Hamil tentang HIV Sebelum Diberikan Penkes dengan Media Booklet}

\begin{tabular}{lcc}
\hline Tingkat pengetahuan & F & \% \\
\hline Baik & 50 & 52,0 \\
\hline Cukup & 5 & 5,2 \\
\hline Kurang & 41 & 42,9 \\
\hline Total & $\mathbf{9 6}$ & $\mathbf{1 0 0}$ \\
\hline
\end{tabular}

Berdasarkan tabel 1 diketahui bahwa rata-rata tingkat pengetahuan tentang pengetahuan ibu hamil sebelum diberikan pendidikan kesehatan tentang HIV dengan media booklet 50 (52\%) ibu hamil memiliki pengetahuan yang baik.

Tabel 2 Distribusi Frekuensi Perilaku Ibu Hamil Sebelum Diberikan Pendidikan Kesehatan tentang Deteksi Dini HIV dari Ibu Ke Bayi dengan Menggunakan Media Booklet.

\begin{tabular}{lcc}
\hline $\begin{array}{c}\text { Deteksi Dini HIV } \\
\text { pada Ibu dan Bayi }\end{array}$ & F & \% \\
\hline Tinggi & 30 & 31 \\
\hline Rendah & 66 & 69 \\
\hline Total & $\mathbf{9 6}$ & $\mathbf{1 0 0}$ \\
\hline
\end{tabular}

Berdasarkan tabel 2 diketahui bahwa ratarata perilaku ibu hamil sebelum diberikan Jurnal Penelitian Kesehatan STIKes Dharma Husada Bandung pendidikan kesehatan tentang deteksi dini HIV dari ibu ke bayi dengan media booklet 66 (69\%) ibu hamil memiliki perilaku yang rendah

Tabel 3 Distribusi Frekuensi Tingkat Pengetahuan Ibu Hamil tentang HIV Setelah Diberikan Penkes dengan Media Booklet.

\begin{tabular}{lcc}
\hline Tingkat pengetahuan & F & \% \\
\hline Baik & 87 & 91 \\
\hline Cukup & 9 & 9 \\
\hline Kurang & 0 & 0 \\
\hline Total & $\mathbf{9 6}$ & $\mathbf{1 0 0}$ \\
\hline
\end{tabular}

Berdasarkan tabel 3 Dapat diketahui bahwa rata-rata tingkat pengetahuan tentang pengetahuan ibu hamil setelah diberikan pendidikan kesehatan tentang HIV dengan media booklet memiliki peningkatan yang signifikan menjadi 87 (91\%) ibu hamil memiliki pengetahuan yang baik

Tabel 4 Distribusi Frekuensi Perilaku Ibu Hamil tetelah Diberikan Pendidikan Kesehatan tentang Deteksi Dini HIV dari Ibu Ke Bayi Dengan Menggunakan Media Booklet.

\begin{tabular}{lcc}
\hline $\begin{array}{c}\text { Deteksi Dini HIV } \\
\text { pada Ibu dan Bayi }\end{array}$ & F & \% \\
\hline Tinggi & 90 & 94 \\
\hline Rendah & 6 & 6 \\
\hline Total & $\mathbf{9 6}$ & $\mathbf{1 0 0}$ \\
\hline
\end{tabular}

Berdasarkan tabel 4 Dapat diketahui bahwa rata-rata perilaku ibu hamil setelah diberikan pendidikan kesehatan tentang deteksi dini HIV dari ibu ke bayi dengan media booklet mengalami peningkatan yang signifikan yaitu 
sebanyak 99 (94\%) ibu hamil memiliki perilaku yang tinggi

\section{B. Pembahasan}

Tingkat pengatahuan sebelum diberi pendidikan kesehatan tentang pengetahuan HIV dengan menggunakan media booklet memiliki hasil yang baik sebanyak 52\% dan setelah diberikan pendidikan kesehatan tentang HIV dengan media booklet mengalami peningkatan yang signifikan menjadi $91 \%$. Hasil penelitian yang dilakukan secara signifikan berbeda antara pretest dan posttest $(\mathrm{p}<0,05)$.

Pemberian pendidikan kesehatan pada ibu hamil tentang HIV dengan menggunakan media booklet membuat ibu hamil tertarik untuk memperhatikan informasi yang disampaikan terkait pengertahuan tentang HIV, cara penularan dan cara pencegahannya. Sehingga pengetahuan mengalami peningkatan. Booklet merupakan media edukasi yang menarik dan tidak membosankan bagi ibu hamil. Penelitian Hamida (2012), menemukan bahwa media yang digunakan dalam proses pembelajaran menyebabkan proses pembelajaran menjadi lebih menarik perhatian sehingga lebih mudah diimplementasikan serta sasaran tidak menjadi cepat bosan. Hal ini didukung dengan hasil penelitian Rufiati (2011), dan Zulaekah (2012) yang menemukan bahwa penggunaan media dalam mempersembahkan edukasi dapat mempengaruhi peningkatan pengetahuan.

Memberikan pendidikan kesehatan dengan menggunakan media booklet pada ibu hamil ini tentunya tidak hanya terbatas pada materi tentang pengetahuan HIV saja, akan tetapi untuk hal-hal lain dimana kebutuhan peningkatan pengetahuan diperlukan pada berbagai aspek karena selama ini permainan kata-kata mereka dihadapkan pada permasalahan-permasalahan yang mereka sendiri perlu mendapatkan bantuan. Dengan pengetahuan yang cukup diharapkan mereka dapat mengaflikasikan kedalam prilaku sehingga dapat menghindari hal-hal yang dapat menimbulkan terjadinya penularan HIV dari ibu ke bayi.

Selain itu, berdasarkan hasil penelitian pada ibu hamil diperoleh hasil bahwa tingkat perilaku sebelum diberi pendidikan kesehatan tentang deteksi dini HIV dari ibu ke bayi dengan menggunakan media booklet memiliki hasil yang rendah sebanyak $69 \%$ dan setelah diberikan pendidikan kesehatan tentang HIV dengan media booklet mengalami peningkatan yang signifikan menjadi 94\%. Hasil penelitian yang dilakukan secara signifikan berbeda antara pretest dan posttest $(\mathrm{p}<0,05)$.

Peningkatan Perilaku dalam pemberian pendidikan kesehatan tentang deteksi dini HIV pada ibu hamil ke bayi dengan menggunakan media booklet membuat ibu hamil menyadari pentingnya melakukan pemeriksaan dan berencana akan segera melakukan pemeriksaan karena mengkhawatirkan keselamatan diri dan janin yang sedang dikandungnya. Perilaku merupakan suatu kegiatan atau aktivitas yang 
bersangkutan, oleh sebab itu, dari sudut pandang biologis mulai dari mahluk hidup, tumbuh-tumbuhan, binatang sampai dengan manusia itu berprilaku, karena mereka mempunyai aktivitas masing-masing. (Notoatmojo, 2007)

Mengubah perilaku pendidikan kesehatan dengan menggunakan media booklet pada ibu hamil dalam rangka sebagai upaya deteksi dini terjadinya penularan HIV dari ibu ke bayi ini tentunya tidak hanya terbatas pada materi tentang prilaku deteksi dini HIV saja, akan tetapi untuk hal-hal lain dimana kebutuhan peningkatan perilaku diperlukan pada berbagai aspek karena selama ini masih dihadapkan pada permasalahan-permasalahan yang mereka sendiri perlu mendapatkan bantuan. Dengan terjadinya perubahan perilaku yang signifikan diharapkan mereka dapat mengaflikasikan kedalam prilaku sehingga dapat menghindari hal-hal yang dapat menimbulkan terjadinya penularan HIV dari ibu ke bayi.

\section{SIMPULAN}

a. Distribusi frekuensi pengetahuan HIV dengan menggunakan media booklet memiliki hasil yang baik sebanyak 52\% dan setelah diberikan pendidikan kesehatan tentang HIV dengan media booklet mengalami peningkatan yang signifikan menjadi $91 \%$.

b. Distribusi frekuensi tingkat perilaku sebelum diberi pendidikan kesehatan tentang deteksi dini HIV dari ibu ke bayi dengan menggunakan media booklet memiliki hasil yang rendah sebanyak 69\% dan setelah diberikan pendidikan kesehatan tentang HIV dengan media booklet mengalami peningkatan yang signifikan menjadi $94 \%$.

\section{DAFTAR PUSTAKA}

Adaji, S. E., Warenius, L. U., Ongany, A.,A., \& Faxelid, E. A. (2010). The attitudes of kenyan in-school adolescents toward sexual autonomy. African Journal of Reproductive Health, 14(1), 33-41. Juni 15, 2012.

Ahrold, T. K., \& Meston, C. M. (2010). Ethnic differences in sexual attitudes of

U.S. college students: Gender, acculturation, and religiosity factors. Archives of Sexual Behavior, 39(1), 190-202. Juni 23, 2012.

Alimul H., A. (2003). Riset keperawatan \& teknik penulisan ilmiah. Ed 1. Jakarta: Salemba Medika.

Anderson, J., et. al. (1990). HIV/AIDS knowledge and sexual behavior among high school students. Journal of Family Planning Perspectives, 22(6), 252-255. Maret 3, 2012.

Azwar, S. (2005). Sikap Manusia: teori dan pengukurannya. Yogyakarta: Pustaka Pelajar.

Badan Pusat Statistik. (2010). Jumlah jenis kelamin berdasarkan kelompok umur.

Juni, 2012. http://www.bps.go.id.

Badan Pusat Statistik. (2011). Jumlah dan persentase penduduk miskin, garis kemiskinan, indeks kedalaman kemiskinan (p1), dan indeks keparahan kemiskinan (p2) menurut provinsi. Juni, 2012. http://www.bps.go.id. 
Bekti (2010). Remaja rentan terkena HIV/AIDS. Oktober 2, 2011. http://medicastore.com/artikel/324/Remaj a_dan_HIVAIDS.html

BKKBN: Masih rendah pengetahuan remaja tentang kesehatan reproduksi. (2009). Oktober 3, 2011.

http://www.waspada.co.id/index.php?option=c om_content\&view $=$ article\&id $=$ 62110:bkkbn-masih-rendah-pengetahuanremaja-tentang-kesehatanreproduksi\&catid $=15 \&$ Itemid $=28$

Boyke (2009). Remaja dan hubungan seksual pranikah. Maret 7, 2012.

http://www.remajaindonesia.org/forum/to pic/79-

REMAJA_DAN_HUBUNGAN_SEKSU AL PRANIKAH.html

Dahlan, M. S. (2009) Besar sampel dan cara pengambilan sampel dalam penelitian kedokteran dan kesehatan. Ed 2. Jakarta: Salemba Medika

Darmasih, R. (2009). Faktor yang mempengaruhi perilaku seks pranikah pada remaja SMA di Surakarta. Universitas Muhammadiyah Surakarta, Surakarta, Indonesia. Maret 8, 2011.

http://etd.eprints.ums.ac.id/5959/1/J410050007 .PDF Depkes. (2011).

Laporan triwulan pertama 2011 Kasus HIVAIDS. Oktober 2, 2011.

http://www.depkes.go.id/index.php/berita/press -release/1496-laporan-

triwulan-pertama-2011-kasus-hiv-aids.html

Dessirya, E. dan Lasma (2008). Pengetahuan, kesalahpahaman dan sikap remaja terhadap HIV/AIDS di suatu sekolah menengah umum di daerah sub urban di Bekasi. Laporan Penelitian tidak dipublikasikan, Universitas Indonesia, Depok, Indonesia.

Dewi, P. (2008). Pengetahuan siswa SMU Negeri 39 Cijantung, Jakarta Timur, tentang HIV/AIDS tahun 2008. Maret 8, 2012. http:// www.lontar.ui.ac.id\%2Ffile\%3Ffile\%3Dd igital\%2F124086-S-5242-

Pengetahuan\%2520siswaAbstrak.pdf\&ei=RJNYT7OJOomGrAfG4 ummDA\&usg=AFQjCNFtUZeWH TtUl4pqcqOwNyQ8tKw8pQ

Durojaiye, O. (2011). Knowledge, attitude and practice of HIV/AIDS: Behavior change among tertiary education students in lagos, nigeria. Annals of Tropical Medicine and Public Health, 4(1), 18-24 Juni 23, 2012.

Felicia, N. (2011). Pelajaran bahaya HIVAIDS masuk mata pelajaran. Oktober 2, 2011.

http://www.beritasatu.com/articles/read/2 011/9/6216/pelajaran- bahaya-hiv-aidsmasuk-mata-pelajaran

Hastono, S. P. (2007). Analisis Data Kesehatan. Depok: Fakultas Kesehatan Masyarakat Universitas Indonesia

Hidayana, et al. (Ed). (2004). Seksualitas: teori dan realitas. Jakarta: Program Gender dan Seksualitas FISIP UI bekerja sama dengan The Ford Foundation.

Husodo, B. T. et al. (2008, Desember). Pengetahuan dan sikap konselor SMP dan SMA dalam penyuluhan kesehatan reproduksi di kota Semarang. Jurnal Makara Kesehatan, 13 (2), 69-62. September 28, 2011. 